\title{
The Variation of Scour Depth near Vertical and Inclined Cylindrical Bridge Piers: An Experimental Study
}

\author{
Aysar Tuama Al-Awadi \\ Projects and Construction Department, University of Kerbala, Kerbala 56001, Iraq
}

Corresponding Author Email: Aysar.t@uokerbala.edu.iq

https://doi.org/10.18280/mmep.080515

Received: 10 April 2021

Accepted: 20 July 2021

\section{Keywords:}

scour depth, bridge piers, inclined piers, vertical piers, flow intensity, modified empirical formula

\begin{abstract}
The stability of bridge piers against scouring phenomena require to estimate the scour depth carefully at different hydraulic condition to ensure safe design. In this study, laboratory experiments were carried out to examine and compare the scour depth for vertical and inclined cylindrical piers with downstream direction under clear water scour conditions. The measured scour depth in front of three inclined configurations $(\theta$ $=10^{\circ}, 16^{\circ}$ and $22^{\circ}$ ) for single cylindrical pier was compared to that observed at vertical cylindrical pier $\left(\Theta=0^{\circ}\right)$. The experiments were conducted at four flow intensities $(\mathrm{V} / \mathrm{VC}=0.495,0.714,0.824$ and 0.989$)$ for sand bed material of $\mathrm{d} 50=0.72 \mathrm{~mm}$. The obtained results revealed and confirmed the inverse relationship between the measured scour depth and the angle of inclination of pier, whereas the maximum and the minimum scour depth was observed at $\Theta=0^{\circ}$, and $\Theta=22^{\circ}$ respectively. The results of this study showed that the scour depth near threshold conditions $(\mathrm{V} / \mathrm{VC}=0.989)$ can be reduced approximately by $(5 \%, 10 \%$, and $15 \%)$ for inclined piers with $\left(\Theta=10^{\circ}, 16^{\circ}\right.$ and $\left.22^{\circ}\right)$ respectively. Furthermore, by assessment of five existing formulas, new modified empirical formula has been proposed for scour depth estimation of inclined piers with $\pm 9 \%$ error margins.
\end{abstract}

\section{INTRODUCTION}

The morphological and the hydraulic conditions of scouring phenomena around bridge piers may reduce the risk of collapse and failure of bridges. For many years, various studies have been conducted to understand the complicated mechanism of scour around bridge piers and explain the effect of functional parameters on flow patterns, scour hole morphology and scour depth prediction [1-9]. However, for the aim of decreasing the strength of the erosive action of water and to consider the modern design of bridges, inclined piers were clearly seen in many countries. Until now, few laboratory studies focused on the associated scour depth with inclined bridge piers. Based on the experimental results [10], a significant relation was revealed between the slope of tapered piers and scour depth. Their study showed that the scour depth clearly affected by the upward slope of tested piers, thus the scour depth increases with increase the width of tapered piers from the bottom toward the top, while narrowing these piers upwardly decreases the depth of scour. Bozkus and Yildiz [11], performed laboratory study to investigate the effect of inclined cylindrical piers on local scour depth for uniform sand bed with two medians diameter $\left(\mathrm{d}_{50}=0.5 \mathrm{~mm}\right.$, and $1 \mathrm{~mm})$ under different flow intensities range $\left(\mathrm{V} / \mathrm{V}_{\mathrm{C}}\right.$ from 1.2 to 1.86$)$. The authors conducted 44 experiments according to four angles of inclination $\left(\Theta=2^{\circ}, 5^{\circ}, 10^{\circ}\right.$ and $\left.15^{\circ}\right)$. The results of their study concluded that the scour depth decreases substantially as the angle of inclination increase downwardly with flow direction, also new empirical formulas were proposed. Experimental study was presented by Ozlap [12], to show the effect of inclination piers group with stream wise direction on scour depth for uniform bed material of $\mathrm{d}_{50}=0.88$ $\mathrm{mm}$ under clear water condition. The experiments have been carried out with three angles $\left(\Theta=0^{\circ}, 10^{\circ}\right.$, and $\left.15^{\circ}\right)$, the spacing between piers were fixed at four times of pier diameter (4D) with respect to different arrangement of piers group with 72 tests. Their study confirmed that there is a clearly reduction in scour depth for upstream piers related to the increase of angle of inclination. The scour hole dimensions decrease obviously by increasing the angle of piers inclination according to the laboratory results for series of experiments (32 tests for $\Theta=0^{\circ}, 7^{\circ}, 14^{\circ}$ and $21^{\circ}$ ) under clear water conditions for uniform sediment of $\mathrm{d}_{50}=0.6 \mathrm{~mm}$ [13]. Karimi et al. [14], examined four inclination piers with downstream side $\left(\Theta=0^{\circ}, 5^{\circ}, 10^{\circ}\right.$ and $\left.15^{\circ}\right)$ and their effects on scour hole dimensions for sand bed material of $\mathrm{d}_{50}=1.46 \mathrm{~mm}$ with varied flow rates (12 to $18 \mathrm{l} / \mathrm{s}$ ), they concluded that the maximum scour depth occurs with piers angle $\left(\Theta=0^{\circ}\right)$, while the minimum depth of scour occurs at $\Theta=15^{\circ}$. Omara et al. [15], conducted extensive experimental study for investigating the inclination effect of different piers geometry (square, rectangular and circular) on dimension less scour depth (ds/D) for two bed materials $\left(\mathrm{d}_{50}=0.6\right.$ and $\left.0.81 \mathrm{~mm}\right)$. The study included the effect of flow depth $(0.048 \mathrm{~m}$ to $0.08 \mathrm{~m})$, and flow intensity $\left(\mathrm{V} / \mathrm{V}_{\mathrm{C}}\right.$ from 0.6 to 1.06 ) beside four inclination angles $\left(\Theta=10^{\circ}, 15^{\circ}, 21^{\circ}\right.$ and $\left.30^{\circ}\right)$. The authors found significant decrease in $(\mathrm{ds} / \mathrm{D})$ with increasing the inclined configuration from $\Theta=10^{\circ}$ to $30^{\circ}$, also they noted that the best reduction in (ds/D) can be achieved for inclined rectangular piers at $\Theta=30^{\circ}$ and length to width ratio ( $\mathrm{L} / \mathrm{W}=7.5)$. Furthermore, the least reduction was obtained with square piers at different configuration angles. Their study showed that the maximum 
reduction percentage for circular piers at $\Theta=30^{\circ}$ can be ranged from $24 \%$ to $35 \%$. Evidently, and due to the scarcity of experiments data for this problem, the present paper was conducted to reveal the effect of pier inclination angles on the scour depth variation for different range of flow intensity based on new experiments under clear water conditions and to introduce new modified empirical formula of scour depth estimation of inclined bridge piers.

\section{MATERIALS AND METHOD}

\subsection{Experimental instrumentation}

The tests of the current study were carried out at private hydraulic lab in university of Kerbala, Iraq. A horizontal rectangular flume of $7 \mathrm{~m}$ long, $0.7 \mathrm{~m}$ wide and $0.5 \mathrm{~m}$ deep of steel frame was used to conduct the laboratory tests. The bed of flume consists of steel plate, while the walls have been cladded by transparence Plexiglas. Two sump tanks supplied the flume with water ( $1.6 \mathrm{~m}$ long, $1.36 \mathrm{~m}$ wide and $0.7 \mathrm{~m}$ deep for each one). An electric pump with maximum flow rate of $26 \mathrm{l} / \mathrm{s}$ withdraws water from the sump tanks to the upper head tank of $1.4 \mathrm{~m}$ long, $0.7 \mathrm{~m}$ wide, and $0.8 \mathrm{~m}$ deep. The discharge at the supplying pipe was measured by calibrated flow and control valve was used to adjust the required flow for the experiments. The downstream end of flume included movable tail gate that was used to adjust the depth of flow for each test. To simulate the scoured area (working section) properly, a false bottom of $2.5 \mathrm{~m}$ long, 0.7 wide, and $0.22 \mathrm{~m}$ deep was provided. At the center of working, a single cylindrical aluminum pier of $\mathrm{D}=0.031 \mathrm{~m}$ diameter was fixed on movable hinge to perform the angle of test. Two steel ramps have been utilized at the upstream entrance and the downstream end of working section which were covered by $0.05 \mathrm{~m}$ concrete layer thickness to maintain the same roughness conditions at the inlet and the outlet of working section. The upstream ramp of $1.3 \mathrm{~m}$ long, $0.7 \mathrm{~m}$ wide, and $0.22 \mathrm{~m}$ in deep provided the suitable transition between the inlet gate of flume and the working section. The downstream ramp consists of a steel box of $0.7 \mathrm{~m} \times 0.7 \mathrm{~m}$, and $0.22 \mathrm{~m}$ deep, Figure 1 . To measure the maximum scour depth in front of simulated pier, a digital point gauge of $0.01 \mathrm{~mm}$ precision was used.

\subsection{Bed material characteristics, experiments condition, and tests execution}

Uniform sand of median diameter $\mathrm{d}_{50}=0.72 \mathrm{~mm}$ and geometric standard deviation $\sigma_{\mathrm{g}}=1.29$ has been placed at the working section as bed material for all tests of this study. According to Raudkivil and Ettema, [2]; Raudkivi [3]; and Melville [7], the bed material can be considered as non-ripples forming $\left(\mathrm{d}_{50}>0.7 \mathrm{~mm}\right)$, and the effects of armoring at the scour hole can be vanished $\left(\sigma_{\mathrm{g}} \leq 1.3\right)$. The clear water condition was achieved for all experiments and the effects of four flow intensities $\left(\mathrm{V} / \mathrm{V}_{\mathrm{C}}=0.495,0.714,0.824\right.$ and 0.989$)$ at flow depth of $11 \mathrm{~cm}$ were investigated, here in $\mathrm{V}$ is the average flow velocity in the flume. This study adopted the approach of Melville [5], to estimate the critical velocity of sand $\left(\mathrm{V}_{\mathrm{C}}\right)$. The considered experiments facilities, sediment features, and the hydraulic conditions that explained previously overcome the effects of sediment size $\left(\mathrm{D} / \mathrm{d}_{50} \geq 25\right)$, flume side wall $(\mathrm{B} / \mathrm{D}>$ 10 , and $\mathrm{B} / \mathrm{Y}>5$ ), and shallowest $(\mathrm{Y} / \mathrm{D} \geq 2.5$ ) ratio, whereas $\mathrm{D}$, $\mathrm{B}$, and $\mathrm{Y}$ is the diameter of pier, flume width, and depth of flow respectively, [2, 3, 7, 16]. A total of 16 tests were performed including the investigation of the effect of four inclination pier angle $\left(\Theta=0,10^{\circ}, 16^{\circ}\right.$ and $\left.22^{\circ}\right)$. For the aim of comparisons of conducted tests, $5 \mathrm{hrs}$ was maintained. This comparison time was adopted for this study after a preliminary run that have been examined for $7 \mathrm{hrs}$ of vertical single cylindrical pier, whereas the observation results indicated that no significant change in scour depth increase after $4 \mathrm{hrs}$. Melville and Chiew [6], concluded that about 50 to $80 \%$ of maximum scour depth may exist at $10 \%$ of the equilibrium time. Zhao et al. [17], showed that the equilibrium time can be achieved when the rate of change is less than $0.03 \mathrm{D}$ per hour after $4.5 \mathrm{hrs}$ run time, so for present work the $5 \mathrm{hrs}$ was applied since it achieves the objectives. For each experiment, the sand area at the working section was levelled carefully, different marked points were used to ensure the level of sand correctly, also the pier was adjusted to the target angle of test by the hinge that was manufactured for this study. In order to prevent the bed material from disturbance and to maintain the clear water conditions, the flume was supplied slowly with water up to the desired discharge while the water depth was regulated by the sluice gate to the flow depth of $(11 \mathrm{~cm})$ (Figure 2). At the end of each experiment, the scoured area was drawn down carefully, then the scour depth was observed and measured using the digital point gauge.

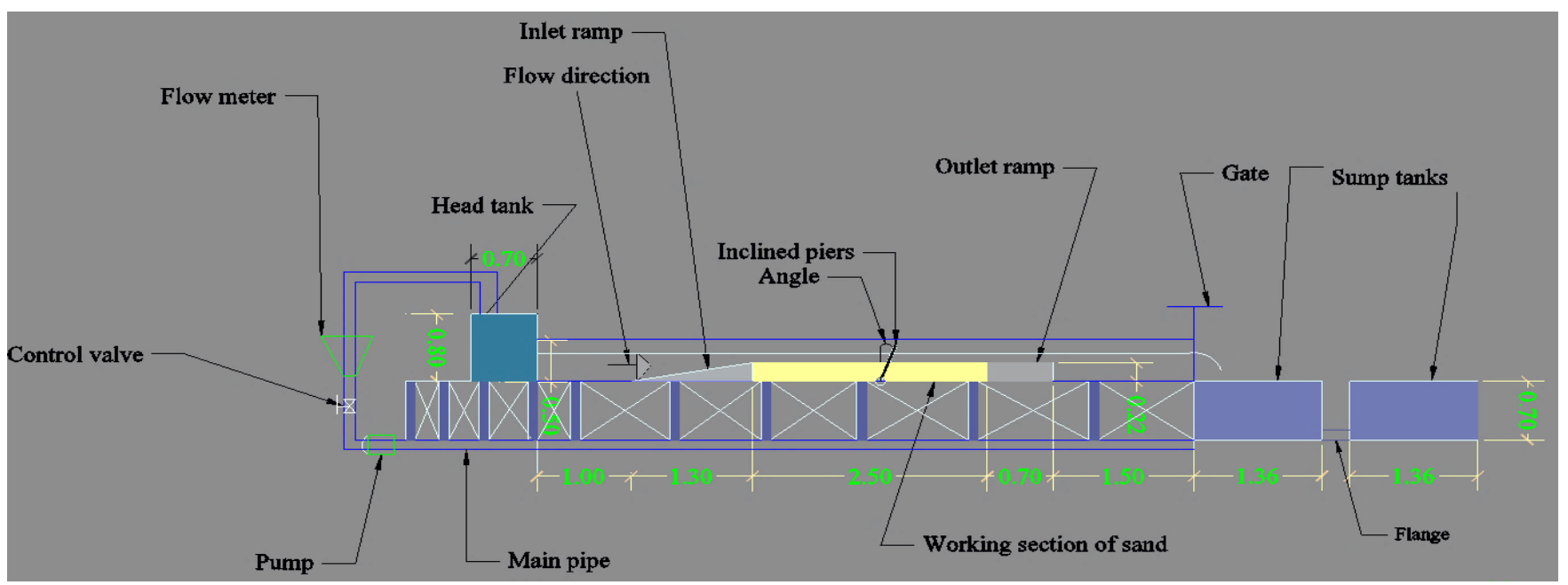

Figure 1. Experimental flume (all dimensions in meter) 


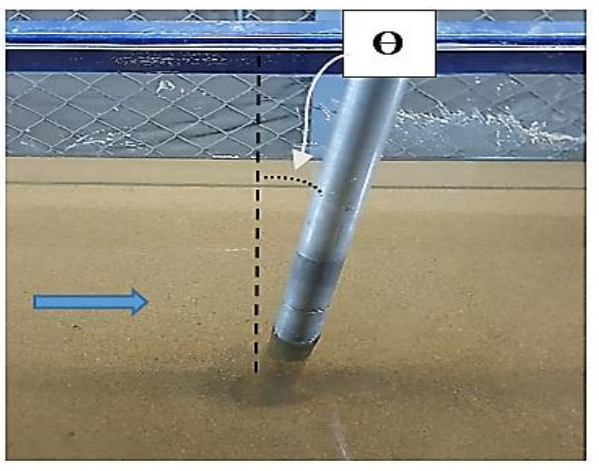

Figure 2. Test conducting at $\Theta=22^{\circ}$

\subsection{Dimensional analysis}

Several influence parameters on scour depth near bridge piers have been recognized by Melville and Chiew [6] Accordingly, the scour depth is a function for these parameters which include fluid flow parameters, sediment parameters, pier characteristics, and time. To consider the effect of pier inclination with downstream direction on maximum scour depth, another parameter should be added and the functional relationship can be written as following:

$$
\mathrm{d}_{\mathrm{sa}}=\mathrm{f}\left(\rho, \mathrm{V}, \mu, \mathrm{Y}, \mathrm{g}, \mathrm{d}_{50}, \rho_{\mathrm{s}}, \mathrm{V}_{\mathrm{C}}, \sigma_{\mathrm{g}}, \mathrm{D}, \Theta\right)
$$

where, $d_{\mathrm{sa}}=$ scour depth with the effect of pier inclination, $\rho=$ water density, $\mathrm{V}=$ mean velocity of flow, $\mu=$ dynamic viscosity of water, $\mathrm{Y}=$ depth of flow, $\mathrm{g}=$ the gravitational acceleration, $d_{50}=$ median particle diameter of bed material, $\rho_{\mathrm{s}}$ $=$ the sediment density, $\mathrm{V}_{\mathrm{C}}=$ critical velocity of bed material, $\sigma_{\mathrm{g}}=$ geometric standard deviation, $\mathrm{D}=$ diameter of pier, and $\Theta$ $=$ pier inclination angle with downstream direction. For this study, the final dimensionless relationship in Eq. (2) was obtained by Buckingham theorem and neglecting the effects of constant term, sediment size, shallowest depth ratio, and considering the turbulence flow nature.

$$
\mathrm{d}_{\mathrm{sa}} / \mathrm{D}=\mathrm{f}_{1}\left(\mathrm{~V} / \mathrm{Vc}, \mathrm{F}_{\mathrm{P}}, \Theta\right)
$$

where $\mathrm{V} / \mathrm{V}_{\mathrm{C}}=$ flow intensity, and $\mathrm{F}_{\mathrm{P}}=\mathrm{V} / \sqrt{\mathrm{gD}}$ (Froude number of pier). The scour depth variation $\left(\mathrm{V}_{\mathrm{R}} \%\right)$ due to pier inclination can be estimated using Eq. (3), where $d_{s}=$ scour depth at $\Theta=0^{\circ}$.

$$
\mathrm{V}_{\mathrm{R}} \%=\frac{d_{s a}-d_{s}}{d_{s}} \times 100
$$

Furthermore, the coefficient of inclination of pier $\left(\mathrm{K}_{\theta i}\right)$ can be estimated as written below in Eq (4):

$$
\mathrm{K}_{\ominus \mathrm{i}}=\frac{d_{s a}}{d_{s}}
$$

\section{RESULTS ANALYSIS AND DISCUSSION}

\subsection{Evaluation of the influence parameters}

Table 1 shows the obtained results for the experiments series of this study. As it is shown, the results are listed according to the effect of flow intensity $(\mathrm{V} / \mathrm{Vc})$. It is observed that, the increasing of angle of pier inclination $(\Theta)$ decreases the scour depth near pier corresponding to the value of $(\mathrm{V} / \mathrm{Vc})$. Figure 3 illustrates the variation of scour depth $\left(\mathrm{d}_{\mathrm{sa}} / \mathrm{D}\right)$ regarding to $(\mathrm{V} / \mathrm{Vc}$ and $\Theta)$. For $\mathrm{V} / \mathrm{V}_{\mathrm{c}}=0.495$ and by increasing $\Theta$ from $0^{\circ}$ to $22^{\circ}$, the observed scour depth $\left(\mathrm{d}_{\mathrm{sa}} / \mathrm{D}\right)$ decreased from 1.194 , to 0.710 , while for $V / \mathrm{V}_{\mathrm{c}}=0.714$ and by the same increasing of $(\Theta),\left(\mathrm{d}_{\mathrm{sa}} / \mathrm{D}\right)$ decreased from 1.452 to 1.129 . Accordingly, by increase $\Theta$ from $0^{\circ}$ to $22^{\circ}$, it is noted from Figure 3 for $V / V_{c}=0.824$ that, $\left(d_{s a} / D\right)$ can be reduced from 1.613 to 1.323 , while for $\mathrm{V} / \mathrm{V}_{\mathrm{c}}=0.989,\left(\mathrm{~d}_{\mathrm{sa}} / \mathrm{D}\right)$ decreased from 1.968 to 1.677 . Figure 4 shows the decrease percentage in scour depth due to the effect of pier inclination $(\theta)$ as compared to the observed scour depth of vertical pier $(\Theta=0)$. It can be clearly noted that, the scour depth has been decreased by $13.514 \%, 32.432 \%$, and $40.541 \%$ at $\mathrm{V} / \mathrm{V}_{\mathrm{c}}=0.495$, and by $11.111 \%, 15.560 \%$, and $22.222 \%$ at $\mathrm{V} / \mathrm{V}_{\mathrm{c}}=0.714$, while at $\mathrm{V} / \mathrm{V}_{\mathrm{c}}=0.824$, it was $8 \%, 12 \%$, and $18 \%$ for $\mathrm{O}=10^{\circ}, 16^{\circ}$ and $22^{\circ}$ respectively. It is observed at the threshold condition of initiation of motion of bed material $\left(\mathrm{V} / \mathrm{V}_{\mathrm{c}}=0.989\right)$, the scour depth can decrease by $4.920 \%, 9.84 \%$, and $14.754 \%$ coinciding with effect of $\Theta=10^{\circ}, 16^{\circ}$ and $22^{\circ}$ respectively. As it is apparent in Figure 4, the maximum percentage decrease was observed at $\Theta=22^{\circ}$ for all ranges of $V / V_{c}$. Generally, the estimated value of decrease proportional to flow intensity $\left(\mathrm{V} / \mathrm{V}_{\mathrm{c}}\right)$ and inclination effect.

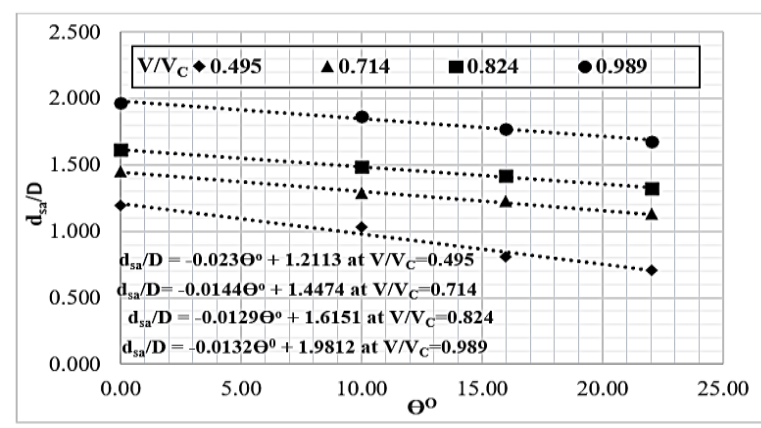

Figure 3. Variation of relative scour depth versus $\Theta$ for different flow intensity

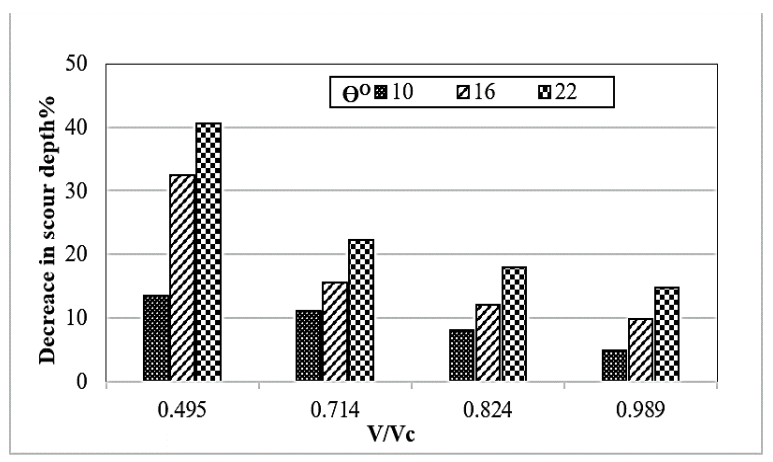

Figure 4. Variation of percentage decrease in scour depth versus $\mathrm{V} / \mathrm{V}_{\mathrm{C}}$ for different $\Theta$

It can be stated that, the increase of $\Theta$ from $10^{\circ}$ to $16^{\circ}$, and $16^{\circ}$ to $22^{\circ}$ increases the percentage reduction by $19 \%$ and $8 \%$ respectively at $\mathrm{V} / \mathrm{V}_{\mathrm{c}}=0.495$, while at $\mathrm{V} / \mathrm{V}_{\mathrm{c}}=0.714$, it can be seen that, the reduction in scour depth increases by $4.489 \%$ and $6.662 \%$ due to the same variation increase of $(\Theta)$. In accordance with effect of increase $(\Theta)$ from $10^{\circ}$ to $16^{\circ}$, and $16^{\circ}$ to $22^{\circ}$, the percentage reduction increases by $4 \%$ and $6 \%$ respectively at $\mathrm{V} / \mathrm{V}_{\mathrm{c}}=0.824$, while at $\mathrm{V} / \mathrm{V}_{\mathrm{c}}=0.989$, it can be specified by $4.920 \%$ and $4.914 \%$. Table 2 summaries a 
comparison for the obtained results of this study and other related work for $\left(\mathrm{V} / \mathrm{V}_{\mathrm{c}} \approx 1\right)$, which reveals the effect of hydraulic condition and pier inclination with downstream direction on the scour depth decrease. Furthermore, the comparison shows the expected amount of decrease in scour depth for several angles. Generally, the decrease in scour depth proportional to strength of downward flow near the pier and the difference in the interaction between approach velocity vector and the angle of pier $(\Theta)$, the increase $(\Theta)$ would lead to reduce the strength of downward flow near the pier face due to separation of the approach velocity into two components as compared with one normal component for vertical pier.

Table 1. Experimental results of this study

\begin{tabular}{|c|c|c|c|c|c|c|c|}
\hline \multicolumn{8}{|c|}{$\mathrm{V} / \mathrm{V}_{\mathrm{c}}=\mathbf{0 . 4 9 5}$} \\
\hline$\theta^{\mathbf{O}}$ & Test & Measured scour, mm & $\mathrm{V} \mathrm{m} / \mathbf{s}$ & $\mathbf{F}_{\mathbf{p}}$ & $\mathbf{d}_{\mathrm{sa}} / \mathbf{D}$ & $\mathrm{V}_{\mathrm{R}} \%$ & $\mathbf{K}_{\boldsymbol{\theta i}}$ \\
\hline 0 & EA & 37 & 0.162 & 0.294 & 1.194 & ---- & 1 \\
\hline 10 & EA1 & 32 & 0.162 & 0.294 & 1.032 & -13.514 & 0.865 \\
\hline 16 & EA2 & 25 & 0.162 & 0.294 & 0.806 & -32.432 & 0.676 \\
\hline 22 & EA3 & 22 & 0.162 & 0.294 & 0.710 & -40.541 & 0.595 \\
\hline \multicolumn{8}{|c|}{$\mathrm{V} / \mathrm{V}_{\mathrm{c}}=\mathbf{0 . 7 1 4}$} \\
\hline$\Theta^{\mathbf{O}}$ & Test & $\begin{array}{l}\text { Measured } \\
\text { scour, mm }\end{array}$ & $\mathrm{V}, \mathrm{m} / \mathbf{s}$ & $\mathbf{F}_{\mathbf{p}}$ & $\mathbf{d}_{\mathrm{sa}} / \mathbf{D}$ & $\mathbf{V}_{\mathbf{R}} \%$ & $\mathbf{K}_{\boldsymbol{\theta i}}$ \\
\hline 0 & EB & 45 & 0.233 & 0.423 & 1.452 & ---- & 1 \\
\hline 10 & EB1 & 40 & 0.233 & 0.423 & 1.290 & -11.111 & 0.890 \\
\hline 16 & $\mathrm{~EB} 2$ & 38 & 0.233 & 0.423 & 1.226 & -15.560 & 0.844 \\
\hline 22 & EB3 & 35 & 0.233 & 0.423 & 1.129 & -22.222 & 0.780 \\
\hline \multicolumn{8}{|c|}{$\mathrm{V} / \mathrm{V}_{\mathrm{c}}=\mathbf{0 . 8 2 4}$} \\
\hline$\theta^{\mathbf{O}}$ & Test & $\begin{array}{l}\text { Measured } \\
\text { scour, mm }\end{array}$ & $\mathrm{V} \mathrm{m} / \mathbf{s}$ & $\mathbf{F}_{\mathbf{p}}$ & $\mathbf{d}_{\mathrm{sa}} / \mathbf{D}$ & $\mathbf{V}_{\mathrm{R}} \%$ & $\mathbf{K}_{\boldsymbol{\theta i}}$ \\
\hline 0 & $\mathrm{EC}$ & 50 & 0.269 & 0.488 & 1.613 & ---- & 1 \\
\hline 10 & $\mathrm{EC} 1$ & 46 & 0.269 & 0.488 & 1.484 & -8 & 0.920 \\
\hline 16 & $\mathrm{EC} 2$ & 44 & 0.269 & 0.488 & 1.419 & -12 & 0.880 \\
\hline 22 & $\mathrm{EC} 3$ & 41 & 0.269 & 0.488 & 1.323 & -18 & 0.820 \\
\hline \multicolumn{8}{|c|}{$\mathrm{V} / \mathrm{V}_{\mathrm{c}}=\mathbf{0 . 9 8 9}$} \\
\hline $\boldsymbol{\theta}^{\mathbf{O}}$ & Test & Measured scour, mm & $\mathrm{V} \mathrm{m} / \mathrm{s}$ & $\mathbf{F}_{\mathbf{p}}$ & $\mathbf{d}_{\mathrm{sa}} / \mathrm{D}$ & $\mathbf{V}_{\mathrm{R}} \%$ & $\mathbf{K}_{\boldsymbol{\theta i}}$ \\
\hline 0 & ED & 61 & 0.323 & 0.586 & 1.968 & ---- & 1 \\
\hline 10 & ED1 & 58 & 0.323 & 0.586 & 1.871 & -4.920 & 0.951 \\
\hline 16 & ED2 & 55 & 0.323 & 0.586 & 1.774 & -9.84 & 0.901 \\
\hline 22 & ED3 & 52 & 0.323 & 0.586 & 1.677 & -14.754 & 0.852 \\
\hline
\end{tabular}

Table 2. Comparison of change of decrease scour depth near threshold condition $\left(\mathrm{V} / \mathrm{V}_{\mathrm{c}} \approx 1\right)$ for present study and other studies

\begin{tabular}{cccccc}
\hline Authors & $\mathrm{V} / \mathrm{V}_{\mathrm{c}}$ & Angle of pier inclination in degree & $\mathrm{D} / \mathrm{d}_{50}$ & $\mathrm{Y} / \mathrm{D}$ & \% decrease in scour depth \\
\hline & 1.06 & 10 & & 1.4 & 11.321 \\
& 1.01 & 10 & & 1.5 & 11.765 \\
& 1.06 & 15 & 57 & 1.4 & 16.981 \\
Omara et al. (2020) & 1.01 & 15 & & 1.5 & 19.61 \\
& 1.06 & 21 & & 1.5 & 22.642 \\
& 1.01 & 21 & & 1.4 & 30.53 \\
& 1.06 & 30 & 66.7 & 1.5 & 31.373 \\
& 1.01 & 30 & 83.333 & 3.6 & 5 \\
& 0.98 & 7 & 66.7 & 4.5 & 12.5 \\
Vaghefi et al. (2016) & 0.98 & 7 & 83.333 & 3.6 & 12.9 \\
& 0.98 & 14 & 66.7 & 4.5 & 23.5 \\
& 0.98 & 14 & 83.333 & 3.6 & 21.515 \\
& 0.98 & 21 & & & 4.920 \\
Present study & 0.98 & 21 & 43.1 & 3.55 & 9.84 \\
& 0.989 & 10 & & & 14.754 \\
\hline
\end{tabular}

Table 3. Measured scour depth of this study and estimated by pervious formulas for vertical pier $(\Theta=0)$

\begin{tabular}{|c|c|c|c|c|c|c|}
\hline \multicolumn{7}{|c|}{$\begin{array}{l}\text { V/V } \\
\text { c }\end{array}$} \\
\hline 0.495 & 1.194 & 1.188 & 2.044 & 1.542 & 0.314 & 1.163 \\
\hline 0.714 & 1.452 & 1.714 & 2.198 & 1.801 & 1.862 & 1.537 \\
\hline 0.824 & 1.613 & 1.978 & 2.262 & 1.917 & 2.172 & 1.717 \\
\hline 0.989 & 1.968 & 2.374 & 2.347 & 2.074 & 2.325 & 1.977 \\
\hline & APE\% & 15.451 & 45.515 & 19.354 & 38.684 & 3.839 \\
\hline
\end{tabular}




\subsection{Assessment of scour depth results with existing formulas for vertical $\operatorname{Pier}(\Theta=0)$}

Table 3 illustrates the obtained results of scour depth for vertical pier as compared with that estimated by the most common formulas from previous studies [5, 18-21]. These formulas have been concluded for wide range of experiments and hydraulic condition. The evaluation was conducted according to the accuracy results of each formula using the statistical analysis by mean absolute percentage error (MAPE). As it is apparent in Table 3, the minimum value of MAPE is $3.839 \%$, and it occurs in accordance with the estimated scour depth by Aksoy and Eski [21], so the present results of experiments support using this formula, which can be written as follows:

$$
\mathrm{d}_{\mathrm{s}} / \mathrm{D}=1.39 \times\left(\mathrm{F}_{\mathrm{d}}\right)^{0.77} \times(\mathrm{Y} / \mathrm{D})^{0.036} \times\left(\mathrm{D} / \mathrm{d}_{50}\right)^{-0.194}
$$

where, $F_{d}$ is the densimetric Froude number of bed material, and can be estimated according to Eq. (6):

$$
F_{d}=V / \sqrt{g_{50}}
$$

\subsection{New modified empirical formula}

To develop new empirical formula for scour depth estimation with inclined piers, this study adopted the modification of the empirical formula concluded by Aksoy and Eski [21] using the coefficient of inclination of pier $\left(\mathrm{K}_{\ominus \mathrm{i}}\right)$. Figure 5 shows the trending curves of $\left(\mathrm{K}_{\Theta \mathrm{i}}\right)$ for $\mathrm{V} / \mathrm{V}_{\mathrm{c}}=0.495$ to 0.989 , and $10^{\circ} \leq \Theta \leq 22^{\circ}$, this figure can give a good estimation for the value of $\left(\mathrm{K}_{\ominus \mathrm{i}}\right)$ required to consider the effect of pier inclination. Accordingly, the new modified formula for scour depth estimation of inclined pier can be written as following:

$$
\mathrm{d}_{\mathrm{sa}} / \mathrm{D}=1.39 \times\left(\mathrm{F}_{\mathrm{d}}\right)^{0.77} \times(\mathrm{Y} / \mathrm{D})^{0.036} \times\left(\mathrm{D} / \mathrm{d}_{50}\right)^{-0.194} \times \mathrm{K}_{\Theta \mathrm{i}}
$$

The new modified formula for scour depth estimation near inclined piers can be applied for uniform sediment under clear water condition $\left(\mathrm{V} / \mathrm{V}_{\mathrm{c}}=0.495\right.$ to $0.989,10^{\circ} \leq \Theta \leq 22^{\circ}$, and $1.930 \leq \mathrm{F}_{\mathrm{d}} \leq 3.843$,), which means wide range of flow intensity and applicable configuration of piers inclination. The scatter plot for the measured scour depth of this study and that estimated by the new modified formula Eq. (7) can be shown in Figure 6. It can be clearly seen that, the Eq. (7) showed good agreement for scour depth estimation near inclined piers, whereas, the estimated results fall with $( \pm 9 \%)$ error margins.

\section{CONCLUSIONS}

In this study, experiments have been conducted for different configuration of inclined cylindrical bridge piers, the sour depth near tested piers was analyzed according to the effect of flow intensity and the angle of inclination toward downstream. Through comparing with the observed scour depth near the vertical piers, the results revealed the expected decease in scour depth due to variation of flow intensity and inclined configuration. Accordingly with the increase of pier inclination $\left(\Theta=10^{\circ}\right.$ to $\left.22^{\circ}\right)$, the scour depth can be reduced significantly by $(13.514 \%$ to $40.541 \%),(11.111 \%$ to $22.22 \%)$, ( $8 \%$ to $12 \%$ ), and ( $5 \%$ to $15 \%$ ) for $\mathrm{V} / \mathrm{V}_{\mathrm{c}}=0.495,0.714,0.824$, and 0.989 respectively. On the light of the obtained results of this study and for practical estimation of scour depth of inclined piers, it can be stated that for each $1^{\circ}$, the scour depth decreases by $1.3514 \%, 1.111 \%, 0.8 \%$, and $0.5 \%$ in accordance with $\Theta \leq 10^{\circ}$ for $\mathrm{V} / \mathrm{V}_{\mathrm{c}}=0.495,0.714,0.824$, and 0.989 respectively, while for $10^{\circ} \leq \Theta \leq 16^{\circ}$, each $1^{\circ}$ can decrease the scour depth by $3.153 \%, 0.742 \%, 0.67 \%$, and $0.82 \%$ for the same range of $\mathrm{V} / \mathrm{V}_{\mathrm{c}}$. For $16^{\circ} \leq \mathrm{\theta} \leq 22^{\circ}$, it can be noted that for each $1^{\circ}$, the scour depth decreases by $1.352 \%, 1.110 \%, 0.67 \%$, and $0.82 \%$ for $\mathrm{V} / \mathrm{V}_{\mathrm{c}}=0.495,0.714,0.824$, and 0.989 respectively. The assessment of existing formulas for scour depth estimation of vertical piers showed that the developed formula by Aksoy and Eski [21] can give good approximation as compared with observed results of this study. Accordingly, new proposed formula was introduced to estimate the scour depth for inclined piers at different configurations. Good agreement was obtained according to the results of the new modified formula, whereas the estimated scour depth falls with $( \pm 9 \%)$ error.

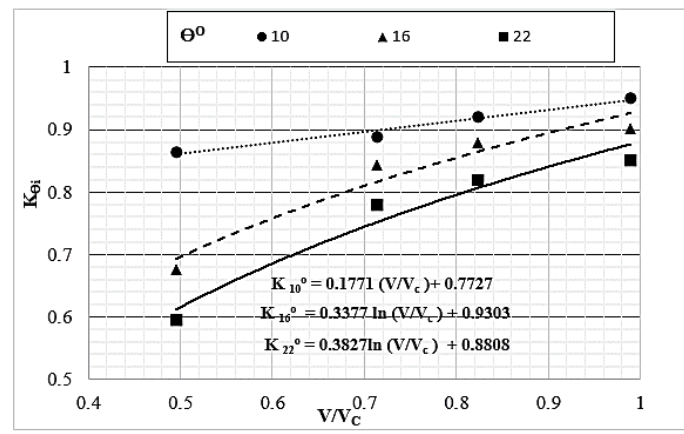

Figure 5. Variation of $\mathrm{K}_{\ominus \mathrm{i}}$ for different flow intensity

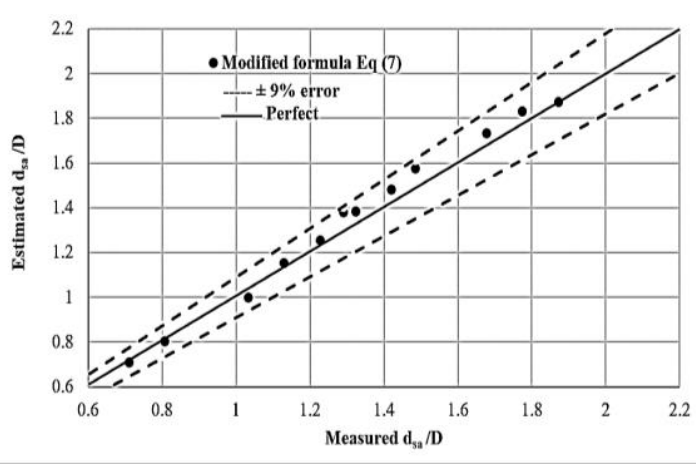

Figure 6. Measured versus estimated by Eq. (7)

\section{REFERENCES}

[1] Breusers, H.N.C., Nicollet, G., Shen, H.W. (1977). Local scour around cylindrical piers. Journal of Hydraulic Research, $15(3)$ : 211-252. https://doi.org/10.1080/00221687709499645

[2] Raudkivi, A.J., Ettema, R. (1983). Clear-water scour at cylindrical piers. Journal of Hydraulic Engineering, 109(3): 338-350. https://doi.org/10.1061/(ASCE)07339429(1983)109:3(338)

[3] Raudkivi, A.J. (1986). Functional trends of scour at bridge piers. Journal of Hydraulic Engineering, 112(1): $1-13$. https://doi.org/10.1061/(ASCE)07339429(1986)112:1(1)

[4] Melville, B.W., Dongol, D.M. (1992). Bridge pier scour with debris accumulation. Journal of Hydraulic 
Engineering,

118(9):

1306-1310.

https://doi.org/10.1061/(ASCE)0733-

9429(1992)118:9(1306)

[5] Melville, B.W. (1997). Pier and abutment scour: Integrated approach. Journal of Hydraulic Engineering, 123(2): 125-136. https://doi.org/10.1061/(ASCE)07339429(1997)123:2(125)

[6] Melville, B.W., Chiew, Y.M. (1999). Time scale for local scour at bridge piers. Journal of Hydraulic Engineering, 125(1): 59-65. https://doi.org/10.1061/(ASCE)07339429(1999)125:1(59)

[7] Melville, B.W. (2008). The physics of local scour at bridge piers. In Proceedings 4th International Conference on Scour and Erosion (ICSE-4), Tokyo, Japan, pp. 28-40.

[8] Pagliara, S., Carnacina, I. (2014). Scour and dune morphology in presence of large wood debris accumulation at bridge pier. Conference Paper, Published Version. German Federal Waterways Engineering and Research Institute. Hydraulic Engineering Repository, pp. 1225-1230.

[9] Al-Awadi, A.T., Al-Khafaji, M.S. (2020). Scour depth at single cylindrical bridge piers with debris jam: An experimental comparative study. In IOP Conference Series: Materials Science and Engineering, 671(2020): 012101. $899 X / 671 / 1 / 012101$

[10] Breusers, H.N.C., Raudkivi, A.J. (1991). Scouring. Hydraulic Structures Design Manual Series, Vol. 2. AA Balkema, Rotterdam, the Netherlands.

[11] Bozkus, Z., Yildiz, O. (2004). Effects of inclination of bridge piers on scouring depth. Journal of Hydraulic Engineering, $\quad 130(8)$ : 827-832. https://doi.org/10.1061/(ASCE)07339429(2004)130:8(827)

[12] Özalp, M.C. (2013). Experimental investigation of local scour around bridge pier groups (Master's thesis). Department of Civil Engineering, Middle East Technical University, Ankara, Turkey.

[13] Vaghefi, M., Ghodsian, M., Salimi, S. (2016). The effect of circular bridge piers with different inclination angles toward downstream on scour. Sadhana, 41(1): 75-86.
https://doi.org/10.1007/s12046-015-0443-X

[14] Karimi, N., Heidarnejad, M., Masjedi, A. (2017). Scour depth at inclined bridge piers along a straight path: A laboratory study. Engineering Science and Technology, an International Journal, 20(4): 1302-1307. https://doi.org/10.1016/j.jestch.2017.07.004

[15] Omara, H., Abdeelaal, G.M., Nadaoka, K., Tawfik, A. (2020). Developing empirical formulas for assessing the scour of vertical and inclined piers. Marine Georesources \& Geotechnology, 38(2): 133-143. https://doi.org/10.1080/1064119X.2018.1559901

[16] Tafarojnoruz, A., Gaudio, R., Grimaldi, C., Calomino, F. (2010). Required conditions to achieve the maximum local scour depth at a circular pier. Proc., XXXII National Congress of Hydraulics and Hydraulic Constructions.

[17] Zhao, M., Cheng, L., Zang, Z. (2010). Experimental and numerical investigation of local scour around a submerged vertical circular cylinder in steady currents. Coastal Engineering, 57(8): 709-721. https://doi.org/10.1016/j.coastaleng.2010.03.002

[18] Ettema, R., Melville, B.W., Barkdoll, B. (1998). Scale effect in pier-scour experiments. Journal of Hydraulic Engineering, $124(6)$ : https://doi.org/10.1061/(ASCE)07339429(1998)124:6(639)

[19] Richardson, E.V., Davis, S.R. (2001). Evaluating scour at bridges (No. FHWA-NHI-01-001). United States. Federal Highway Administration. Office of Bridge Technology.

[20] Sheppard, D.M., Odeh, M.. Glasser, T. (2004). Large scale clear-water local pier scour experiments. Journal of Hydraulic Engineering, 130(10): 957-963. https://doi.org/10.1061/(ASCE)07339429(2004)130:10(957)

[21] Aksoy, A.O., Eski, O.Y. (2016). Experimental investigation of local scour around circular bridge piers under steady state flow conditions. Journal of the South African Institution of Civil Engineering, 58(3): 21-27. https://doi.org/10.17159/2309-8775/2016/V58N3A3 